\title{
Media Audiovisual dalam Menulis Kembali Teks Cerita Fabel oleh Siswa Kelas VIII SMP Swasta Bandung
}

\author{
Oktavia Lestari $\mathbf{P}^{1}$, Fitri Asma ${ }^{2}$ \\ Universitas Muhammadiyah Sumatera Utara \\ oktavialestari@umsu.ac.id
}

\begin{abstract}
Abstrak
Penelitian inibertujuan untuk mengetahui efektivitas media audiovisual dalam menulis kembali teks cerita fabel oleh siswa kelas VIII SMP Swasta Bandung. Populasi penelitian adalah seluruh siswa kelas VIII SMP bandung yang berjumlah 34 orang siswa. Metode yang digunakan adalah metode eksperimen, instrument penelitian yaitu efektivitas media audiovisual dalam menilis teks cerita fabel. Setelah menghitung dan mengolah data dari hasil penelitian yang dilakukan, diperoleh kesimpulan bahwa mengetahui efektivitas media audiovisual dalam menilis teks cerita fabel oleh siswa viii smp swasta bandung berada pada tingkat cukup. Hal ini diketahui dari nilai ratarata yang diperoleh siswa yaitu 72,05 termasuk dalam katagori baik.
\end{abstract}

Kata kunci : Media Audiovisual, Menulis, Teks Cerita Fabel

\section{PENDAHULUAN}

Keterampilan menulis merupakan suatu proses yang kreatif, sebab kegiatan menulis bukan hanya memperkuat ingatan, tetapi memberikan proses berpikir, ketenangan, ketelitian, kehalusan, dan kekayaan yang tidak mungkin dicapai jika tidak ada keterampilan menulis. Menulis merupakan suatu kegiatan yang produktif dan ekspresif.Tarigan (2005:4) kegiatan menulis bertujuan untuk mengungkapkan fakta-fakta, pesan sikap dan isi pikiran secara jelas dan efektif kepada para pembacanya. Sebagai suatu keterampilan berbahasa, menulis merupakan kegiatan yang kompleks karena penulis dituntut untuk dapat menyusun isi tulisannya serta menuangkan dalam formulasi ragam bahasa tulis.Dibalik kerumitannya, menulis banyak mengandung manfaat bagi pengembangan mental, intelektual dan sosial seseorang. Menulis dapat meningkatkan kecerdasan, mengembangkan daya inisiatif, menumbuhkan keberanian, serta merangsang kemauan dan kemampuan mengumpulkan informasi.

Salah satu upaya untuk menghindari kesulitan dalam pembelajaran yaitu dengan menggunakan media 
pembelajaran.Media memiliki fungsi yang sangat penting.Secara umum fungsi media adalah sebagai penyalur pesan. Media pengajaran dapat mempertinggi proses belajar siswa dalam pengajaran yang pada gilirannya dapat mempertinggi hasil belajar yang dicapai (Sudjana, 2008:2).

Cara belajar yang diubah menjadi kreatif dan penggunaan media akan menumbuhkan keinginan serta daya kreativitas siswa. Oleh karena itu berdasarkan latar belakang masalah tersebut peneliti tertarik untuk melakukan penelitian dalam meningkatkan kemampuan menulis kembali teks cerita fabel melalui media audiovisual siswa kelas VIII SMP Swasta Bandung. Berdasarkan hal itu, masalah yang muncul dalam penelitian ini adalah "Bagaimanakah efektivitas media audiovisual dalam menulis kembali teks cerita fabel oleh siswa kelas VIII SMP Swasta Bandung"

\section{KAJIAN TEORI}

\section{Efektifitas}

Dalam Kamus Besar Bahasa Indonesia (Depdiknas, 2008:258) menuliskan bahwa: Efektivitas berasal dari kata efektif yang berarti memiliki efek, pengaruh, akibat. Efektif juga dapat diartikan sebagai memberikan hasil yang memuaskan. Lebih lanjut menurut Kurniawan (2005: 109) menyatakan efektivitas adalah kemampuan melaksanakan tugas, fungsi dalam mencapai suatu misi dan visi yang tidak adanya tekanan selama pelaksanaanya. Efektivitas merupakan suatu ukuran yang menyatakan seberapa jauh suatu target itu tercapai.

\section{Media Pembelajaran}

Arsyad (2013:3-4) mengatakan bahwa, media merupakan segala bentuk dan saluran yang diguanakan dalam proses pencapaian informasi. Sedangkan menurut Hainich, dan kawan-kawan media adalah perantara yang mengantar informasi antara sumber dan penerima. Kemudian menurut Gagne dan Brigs Media adalah meliputi alat yang secara fisik digunakan untuk menyampaikan isi materi pengajaran, yang terdiri antara lain buku, tape recorder, kaset, video camera, video recorder, film, slide (gambar bingkai), foto, gambar, televisi, dan komputer.

Seperti yang dikatakan Lastin, dkk (dalam Arsyad, 2013:81) mengklasifikasikan media ke dalam lima kelompok, yaitu:

1. Media berbasis manusia, seperti guru, instruktur, tutor, main peran, kegiatan kelompok. 
2. Media berbasis cetak, seperti buku pelajaran, buku latihan, dan lain-lain.

3. Media berbasis visual, seperti buku alat bentuk kerja, grafik, peta, gambar dan transparansi.

4. Media audiovisual, seperti video, film, VCD, dan televisi.

5. Media berbasis komputer, seperti pengajaran dengan bantuan komputer.

Dalam pemilihan media pembelajaran harus disesuaikan dengan materi yang diajarkan, seperti yang dikatan Djamar (2006:45), dalam memilih media untuk kepentingan pengajaran sebaiknya memperhatikan kriteria-kriteria sebagai berikut:

1. Ketepatan dengan tujuan pengajaran.

2. Dukungan terhadap isi bahan pelajaran.

3. Kemudahan memperoleh media.

4. Keterampilan guru dalam menggunakannya.

5. Tersedia waktu untuk menggunakannya.

\section{Media Audiovisual}

Menurut Sulaiman (2008:11) bahwa, pengertian audiovisual berasal dari kata "audible" artinya dapat didengar dan "visible" artinya dapat dilihat. Jadi media audiovisual adalah media yang terdiri dari proses pendengaran dan proses penglihatan. Media audiovisual dapat menyampaikan informasi dengan cara yang lebih konkrit atau lebih nyata dari pada disampaikan melalui kata-kata. Ada beberapa kategori media audiovisual yang dapat digunakan dalam pengajaran, yakni:

1. Televisi

Televisi adalah media yang menyampaikan pesan-pesan pembelajaran secara audiovisual dengan disertai unsur gerak dan suara. Dilihat dari sudut jumlah penerima penanyanya, televisi tergolong kedalam media massa.

2. Video

Video adalah media yang menyampaikan pesan-pesan pembelajaran secara audio-visual yang menyampaikan gerak bersama-sama dengan suara. Menurut Arsyad (2013:49) sebagai media pendidikan, video mempunyai kelebihankelebihan sebagai berikut:

a) Video dapat menyajikan berbagai jenis bahan audiovisual termasuk gambar-gambar, film, objek dan drama.

b) Video bisa menyajikan model dan contoh-contoh yang baik bagi siswa.

c) Dapat membawa dunia nyata bagi penyiaran langsung atau rekaman.

d) Video dapat menyajikan visual dan suara yang sangat sulit diperoleh pada dunia nyata, misalnya ekspresi wajah. 
e) Video dapat menghemat waktu guru dan siswa, misalnya dengan merekam siaran pelajaran yang disajikan karena dapat diputar ulang jika diperlukan tanpa harus melakukan proses itu kembali.

Kekurangan video sebagai berikut:

a) Perhatian penonton sulit dikuasai, partisipan mereka jarang diperagakan.

b) Sifat komunikasinya yang bersifat satu arah haruslah diimbangi dengan pencarian bentuk umpan balik yang baik

c) Kurang mampu menampilkan detail dari objek yang disajikan secara sempurna.

d) Memerlukan peralatan yang mahal dan kompleks.

\section{Video Compak Disk (VCD)}

Media Video Compact Disk itu adalah media audiovisual yang dapat menyampaikan pesan dan memancarkan rekaman gambar hidup yang direkam pada disk player.

\section{Pengertian Menulis}

Akhadiah (2003: 41) menyatakan menulis ialah suatu proses, yaitu proses penulisan, proses bernalar, menghubunghubungkan berbagai fakta membandingkan dan sebagainya. Menulis merupakan kemampuan berbahasa yang bersifat produktif artinya menulis itu merupakan kemampuan yang menghasilkan tulisan. Menulis merupakan kegiatan yang memerlukan kemampuan berpikir kompleks. Kemampuan yang diperlukan antar lain kemampuan berpikir secara teratur dan logis, kemampuan mengungkapkan pikiran atau gagasan secara jelas, dengan menggunakan bahasa yang efektif.

Selanjutnya Tarigan (2005:10) juga menyatakan :Menulis adalah menurunkan atau melukiskan lambang-lambang grafik yang menggambarkan suatu bahasa yang dipahami oleh seseorang. Sehingga orang lain dapat membaca lambang-lambang grafik tersebut kalau mereka memahami bahasa dan grafik tersebut. Pengutaraan sesuatu secara tersusun dengan mempergunakan bahasa disebut karangan.Dalam menulis kembali teks cerita fabel, ada beberapa langkah yang harus dilakukan agar hasil menulis kembali teks cerita fabel baik. Menurut Suharman (2006:57) untuk berlatih menulis kembali teks cerita fabel yang pernah dibaca atau di lihat dan didengar bisa melakukan langkah-langkah sebagai berikut:

1. Membaca, melihat atau mendengar fabel yang akan ditulis. 
2. Memperhatikan bagian demi bagian fabel tersebut dari awal sampai akhir. Mengingat urutan cerita dan tokoh fabel.

3. Membayangkan adegan demi adegan dalam fabel seolah-olah terlibat di dalamnya.

4. Mulai menuliskan kembali isi fabel tersebut dengan memperhatikan urutannya dan menggunakan bahasa indonesia yang baik dan benar.

\section{Teks Cerita Fabel}

Dalam Kamus Besar Bahasa Indonesia (Depdiknas, 2008: 572) fabel adalah cerita yang menggambarkan watak dan budi manusia yang pelakunya diperankan oleh binatang (berisi tentang pendidikan moral dan budi pekerti).Cerita yang menggunakan binatang sebagai tokoh-tokohnya untuk mengajarkan moral kepada anak-anak.Sedangkan Nurgiantoro (2005: 190) mengatakan bahwa cerita fabel hadir sebagai personifikasi, baik yang menyangkut penokohan lengkap dengan karakternya maupun persoalan hidup yang diungkapkannya. Artinya, manusia dan berbagai persoalan manusia itu diungkapkan lewat binatang.Mursini (2010:58) menyatakan :Cerita fabel (fables) adalah salah satu bentuk cerita tradisional yang menampilkan binatang sebagai tokoh cerita.Binatang-binatang tersebut dapat berpikir dan berinteraksi layaknya komunikasi manusia, juga dengan permasalahan hidup layaknya manusia yang dapat berpikir, berlogika, berperasaan, berbicara, bersikap, bertingkah laku, sebagaimana layaknya manusia dengan bahasanya.

Sama seperti cerita pendek, novel dan cerita bersambung, cerita fable juga memiliki struktur dalam teks. Seperti yang dikatakan oleh Zabadi dan Sutejo (2014:7) membagi struktur teks cerita fabel menjadi empat yaitu :

1) Orientasi yaitu bagian yang terdapat pada awal cerita, yang berfungsi sebagai pengenal waktu, tempat dan karakter tokoh.

2) Komplikasi yaitu bagian cerita dimana terdappat masalah atau konflik.

3) Resolusi yaitu bagian penyelesaian masalah atau konflik.

4) Koda yaitu pesan moral yang disampaikan pengarang atau perubahan sikap pada tokoh, misalnya tokoh yang jahat berubah menjadi baik.

\section{METODE PENELITIAN}

Penilitian ini menggunakan metode eksperimen dengan post test only control design melibatkan perlakuan berbeda antara dua kelompok. Metode ini 
digunakan dengan tujuan ingin mengetahui efektivitas pada kelompok eksperimen dan kelompok kontrol dalam bentuk pengajaran. Pada kelompok pertama sebagai kelas eksperimen diberikan media audiovisual dalam menulis kembali teks cerita fabel. Kelompok kedua sebagai kelas kontrol diberi pengajaran menulis teks cerita fabel tanpa menggunakan media audiovisual.

\section{HASIL DAN PEMBAHASAN}

Penelitian yang dilakukan di SMP Swasta Bandung ini melibatkan dua kelas yaitu kelas eksperimen dan kelas kontrol.Setelah ditentukan kelas eksperimen dan kelas kontrol kemudian kedua kelas diberikan perlakuan, kelas eksperimen diberi perlakun dan dengan menggunakan media audiovisual dan kelas kontrol tanpa menggunakan media audiovisual.Setelah diberi perlakuan pada kelas eksperimen dan kelas kontrol, kemudian kedua kelas diberikan tes essai menulis kembali teks cerita fabel untuk mengetahui kemampuan akhir siswa. Adapun hasil tes menulis kembali teks cerita fabel kedua kelas adalah : kelompok kelas eksperimen atau kelompok media audiovisual memperoleh mean 72,05 sementara kelompok kontrol yakni kelompok tanpa menggunakan media audiovisual memperoleh mean 58,2. Perolehan mean ini menandakan bahwa kelompok eksperimen memiliki kemampuan yang lebih tinggi dibandingkan kelompok kontrol.

Untuk Menghitung Mean dan Standar Deviasi Kelas Eksperimen

\begin{tabular}{c|c|c|c|c|c}
\hline No & $\mathbf{X}$ & $\mathbf{F}$ & $\mathbf{F X}$ & $\mathbf{X}^{\mathbf{2}}$ & $\mathbf{F X}^{\mathbf{2}}$ \\
\hline 1 & 33 & 2 & 66 & 1.089 & 2.178 \\
\hline 2 & 53 & 3 & 159 & 2.809 & 8.427 \\
\hline 3 & 60 & 4 & 240 & 3.600 & 14.400 \\
\hline 4 & 67 & 6 & 402 & 4.489 & 26.934 \\
\hline 5 & 73 & 4 & 292 & 5.329 & 21.316 \\
\hline 6 & 80 & 6 & 480 & 6.400 & 38.400 \\
\hline 7 & 87 & 4 & 348 & 7.569 & 30.276 \\
\hline 8 & 93 & 5 & 463 & 8.649 & 43.245 \\
\hline & Total & 34 & 2.450 & - & 185.176 \\
\hline
\end{tabular}




$$
\begin{aligned}
& \mathrm{M}=\frac{\sum x}{N} \\
& \mathrm{M}=\frac{2450}{34} \\
& \mathrm{M}=72,05
\end{aligned}
$$

Berdasarkan dari data tersebut, diketahui bahwa nilai rata-rata menulis kembali teks cerita fabel dengan menggunakan media audiovisual adalah 72,05. Jika dikonfirmasikan dengan nilai yang dikemukakan oleh Arikunto (2010:245), sebagai berikut :

$$
\begin{array}{ll}
\text { Nilai 80-100 } & \text { : baik sekali } \\
\text { Nilai 66-79 } & \text { : baik } \\
\text { Nilai 56-65 } & \text { : Cukup } \\
\text { Nilai 40-55 } & \text { : kurang } \\
\text { Nilai 30-39 } & \text { : gagal }
\end{array}
$$

Hal ini berarti menulis kembali teks cerita fabel dengan menggunakan media audiovisual berarti dalam katagori baik.Berdasarkan data tersebut dapat diketahui Frekuensi pada setiap tingkat. Untuk lebih jelasnya dapat dilihat pada tabel berikut :

Tabel 4.3

Distribusi Freskuensi, Presentase dan Katagori Data Kelompok Eksperimen

\begin{tabular}{c|c|c|c|c}
\hline No & Nilai & Frekuensi & Presentase (\%) & Katagori \\
\hline 1 & 33 & 2 & 5,9 & Gagal \\
\hline 2 & 53 & 3 & 8,8 & Kurang \\
\hline 3 & 60 & 4 & 11,8 & Cukup \\
\hline 4 & 67 & 6 & 17,6 & Baik \\
\hline 5 & 73 & 4 & 11,8 & Baik \\
\hline 6 & 80 & 6 & 17,6 & Baik Sekali \\
\hline 7 & 87 & 4 & 11,8 & Baik Sekali \\
\hline 8 & 93 & 5 & 14,7 & - \\
\hline
\end{tabular}

Berdasarkan tabel di atas, siswa yang memperoleh nilai tertinggi yaitu 93 sebanyak 5 siswa $(14,7 \%)$ dan memperoleh nilai terendah yaitu 33 sebanyak 2 siswa $(5,9 \%)$. Secara keseluruhan sebanyak 25 siswa $(73,5 \%)$ memperoleh hasil belajar di atas skor ratarata, sedangkan sisanya sebanyak 9 siswa (26,5\%) memperoleh skor di bawah skor rata-rata pada pembelajaran menulis 
kembali teks cerita fabel dengan menggunakan media audiovisual.

\section{SIMPULAN}

Maka dapat ditarik simpulan bahwa menulis kembali teks cerita fabel dengan menggunakan media audiovisual oleh siswa kelas VIII SMP Swasta Bandungmemperoleh nilai rata-rata 72,05 termasuk dalam katagori baik. Sedangkan jika Menulis kembali teks cerita fabel tanpa menggunakan media audiovisual oleh siswa kelas VIII SMP Swasta Bandung memperoleh nilai rata-rata 58,2 termasuk dalam katagori kurang.Media audiovisual efektif dalam menulis kembali teks cerita fabel, hal ini dibuktikan dari hasil perhitungan dengan uji " $T$ " di peroleh nilai $t_{\text {hitung }}>t_{\text {tabel }}$ pada taraf signifikansi $\alpha=0,05$ dengan $\mathrm{dk}=\left(\mathrm{N}_{1}+\right.$ $\mathrm{N}_{2}$ ) $-2=68$ yaitu $3,825>1,668$ sehingga hipotesis dinyatakan terbukti kebenarannya. Pada penelitian ini terdapat perbedaan yang signifikan dalam menggunakan media audiovisual dengan tanpa menggunakan media audiovisual dalam menulis kembali teks cerita fabel oleh siswa kelas VIII SMP Swasta Bandung, yakni media audiovisual nyatanya membuat siswa lebih baik dalam menulis kembali teks cerita fabel.
Berdasarkan analisis data dan uji statistika pada bab keempat, maka ditetapkan beberapa kesimpulan sebagai berikut :

1. Menulis kembali teks cerita fabel menggunakan media audiovisual oleh siswa kelas VIII SMP Swasta Bandung memperoleh nilai rata-rata 72,05 termasuk dalam katagori baik.

2. Menulis kembali teks cerita fabel tanpa menggunakan media audiovisual oleh siswa kelas VIII SMP Swasta Bandung tahun pembelajaran 2014-2015 memperoleh nilai rata-rata 58,2 termasuk dalam katagori kurang.

3. Media audiovisual efektif dalam menulis kembali teks cerita fabel, hal ini dibuktikan dari hasil perhitungan dengan uji " $T$ " di peroleh nilai $t_{\text {hitung }}>$ $\mathrm{t}_{\text {tabel }}$ pada taraf signifikansi $\alpha=0,05$ dengan $d k=\left(N_{1}+N_{2}\right)-2=68$ yaitu $3,825>1,668$ sehingga hipotesis dinyatakan terbukti kebenarannya.

4. Terdapat perbedaan yang nyata menggunakan media audiovisual dengan tanpa menggunakan media audiovisual dalam menulis kembali teks cerita fabel oleh siswa kelas VIII SMP Swasta Bandung, yakni media audiovisual nyatanya membuat siswa lebih baik dalam menulis kembali teks cerita fabel. 


\section{DAFTAR PUSTAKA}

Akhadiah, S, M.G. 2003. Pembinaan Kemampuan Bahasa Indonesia. Jakarta: Erlangga.

Arikunto, Suharsimi, 2010. Prosedur Penelitian Suatu Pendekatan Praktik. Yogyakarta: Rineka Cipta .

Arsyad, Azhar. 2013 Media Pengajaran. Jakarta: Raja Grafindo persada.

Depdiknas.2008. Kamus Besar Bahasa Indonesia Edisi Keempat. Jakarta: Balai Pustaka.

Djamar, 2006. Strategi Belajar Mengajar. Jakarta: Rineka Cipta.

Mursini, 2010. Bimbingan Apresiasi Sastra Anak-anak. Medan: USU Press. Rosda Karya.

Sudjana, Dr. Nana. 2008. Penelitian Hasil Proses Belajar Mengajar. Bandung: Remaja

Suharman, 2006. Bahasa dan Sastra Indonesia Kelas VII.Bogor: Yudistira.

Sulaiman, Amir Hamzah. 2008. Media Audio-Visual untuk Pengajara, Penerapan, Penyuluhan. Jakarta: PT. Gramedia.

Tarigan, Hendri. 2005. Menullis Sebagai Suatu Keterampilan Berbahasa. Bandung: Angkasa

Zabadi dan Sutejo. 2014. Bahasa Indonesia Wahana Pengetahuan. Jakarta : Kementerian Pendidikan dan Kebudayaan Republik Indonesia. 